\title{
Téoros
}

Revue de recherche en tourisme

\section{Ireland and the French Tourism Market}

Changing Images

\section{Sinead O’Leary et Geraldine Sheridan}

Volume 21, numéro 2, été 2002

URI : https://id.erudit.org/iderudit/1072407ar

DOI : https://doi.org/10.7202/1072407ar

Aller au sommaire du numéro

Éditeur(s)

Université du Québec à Montréal

ISSN

0712-8657 (imprimé)

1923-2705 (numérique)

Découvrir la revue

Citer cet article

O'Leary, S. \& Sheridan, G. (2002). Ireland and the French Tourism Market: Changing Images. Téoros, 21(2), 49-55. https://doi.org/10.7202/1072407ar d'utilisation que vous pouvez consulter en ligne.

https://apropos.erudit.org/fr/usagers/politique-dutilisation/ 


\section{Ireland \\ and the French Tourism Market \\ Changing Images}

\section{Sinead O'Leary and Geraldine Sheridan}

Vu la stagnation récente du nombre de visiteurs français qui arrivent en Irlande, une enquête a été menée à l'été 1998 dont les objectifs étaient :

- d'établir les images de l'Irlande qui aient pu influencer le choix de destination des nouvelles arrivées,

- de cerner l'évolution de ces images au cours de la visite, grâce à un deuxième questionnaire distribué au départ.

L'analyse des données indique que l'image traditionnelle de l'Irlande en tant qu'île aux paysages magnifiques correspond encore à une appréciation positive dans la réalité ; les visiteurs ont aussi évalué positivement certains effets $d u$ "Tigre Celtique», y compris l'amélioration des services (restaurants, magasins) et l'urbanisation. Mais ils ont évalué négativement, par rapport à leurs attentes, d'autres aspects qui peuvent être également attribués aux effets $d u$ développement économique, dont la détérioration de l'environnement, l'accélération du rythme de la vie et un accueil moins chaleureux. Les résultats du sondage suggèrent que les autorités responsables du tourisme en Irlande seront appelées à reconsidérer la promotion traditionnelle de l'Irlande en tant que pays pré-moderne où règnent calme et simplicité.

\section{Introduction}

$\mathbf{T}$ ourism in Ireland has undergone spec tacular developments since the late 1980s. During the period 1988 to 1999 , tourist arrivals rose from 2.1 million to almost six million. Similarly, total foreign exchange earnings increased dramatically over that period, from IR£841 million in 1988 to IR£2.5 billion by 1999 (Bord Fáilte, 2000a). However, recent trends suggest that visitors from France, one of Ireland's main source markets, may have peaked. Even though the number of French visitors to Ireland expanded considerably during the 1980s and the 1990s, and France is now the fourth most important source market for Irish tourism, Ireland has recently experienced a decline in market shares of French trips to Europe. There have been decreases in the number of French visitors coming to Ireland purely to take a holiday, as well as the number of repeat visits and the number of visitors participating in either sporting or cultural activities (Bord Fáilte, 2000a). Overall, Ireland's share as a percentage of French trips to Europe declined from $2.1 \%$ in 1994 to $1.6 \%$ in 1998 (Department of Tourism, Sport and Recreation, $2000: 29$ ).

One of Ireland's most significant challenges arising from the increasingly competitive global tourism environment is the need for an effective destination positioning strategy. Changing consumer profiles and threats to the "people, pace and place" image of Ireland-which has dominated the marketing strategy of Bord Fáilte (the Irish National Tourist Board) from its inception in 1952-highlight the need for research to reassess the images of Ireland that are dominant in the populations on which that country has traditionally depended for as regards the number of visitors. Goodall (1992) suggests that where prices are comparable, image is the decisive factor in holiday choice. Needs and desires predetermine motivations, but while motivations affect the propensity to travel in a general sense, they do not influence the decision to choose a specific destination. As images have been shown to form the basis of the evaluation or selection process, and provide the link between motivations and destination selection (Goodall, 1992), we can infer that image studies are a prerequisite to a successful marketing strategy. The important role of a destination image with respect to the potential tourist's decision-making process is frequently acknowledged in tourism literature (Hunt, 1975; McInnis and Price, 1987; Kent, 1991). Moreover, the fact that "an image, whether positive or negative may continue long after the factors that moulded it have changed" (Fakeye and Crompton, 1991 : 10) emphasises the need for tourism destinations to develop and maintain a positive, yet accurate image. ${ }^{1}$

Images are also significant because of their impact on the level of satisfaction with the tourist experience (Chon, 1990; Pizam and Milman, 1993; Dann, 1996). This is critical as regards positive word-of-mouth recommendations from family and friends and repeat visits to the destination, and it underscores the need to ensure that Ireland's image as portrayed internationally is consistent with what the destination has to offer. Several studies bear testament to the key role played by family and friends in choosing a destination (Jenkins, 1978; McClellan and Fouschee, 1983; Van Raaij 
and Francken, 1984; Mill and Morrison, 1992; Jackson et al., 1997; Vogt et al., 1998; Baloglu and McCleary,1999).

Numerous researchers investigating the processes of image formation and measurement have used Gunn's seven-stage theory (1972) as a basis for their conceptual framework. Gunn's theory involves a constant building and modification of images that are conceived at a number of levels, namely, organic, induced, and modified induced. Organic images are those that arise from supposedly unbiased sources such as books, school, television documentaries, and the experience of friends and family. Induced images emanate from the destination area itself and are derived from marketing and promotional material. The key difference between organic and induced images is the control of the destination area over what is presented. While little can be done to influence organic images, marketers can induce an image through promotional investments (Fayeke and Crompton, 1991). Modified-induced images are the result of personal experiences of the destination. The distinction between organic and induced images, as identified by Gunn, is unique to the formation of destination images. Information for the majority of products and services is primarily commercial in nature; consequently, the role of outside influences in formulating product images is rather limited. Tourism images, on the other hand, are derived from a number of different sources, both commercial and non-commercial, and there is a strong link between a country's tourism image and its national image; they may reflect many different aspects of reality, whether cultural, economic, historical, media-based, political, or social. It must be acknowledged, therefore, that destination images are formed from a wide variety of sources over which the tourism industry has little or no control.

\section{The Destination Image of Ireland}

The international appeal of Ireland as a tourism destination has been based on its scenery and people since Victorian times.
Romantic travel literature, which found its theoretical underpinnings in accounts of the beautiful, the sublime and the picturesque, particularly in the works of the Irishman Edmund Burke ${ }^{3}$ (Butler, 1998), had led to a shift away from the classical aesthetic requirements of regularity and harmony to the more unstructured appearance of landscape, and stimulated an increased interest in sightseeing throughout the less developed parts of Europe, such as the Lake District in Great Britain, the Swiss Alps, and western areas of Ireland such as Killarney. Deliberate promotion of selected images of Ireland began as far back as 1894, when the first issue of The Irish Tourist expressed the hope that Ireland would "attract multitudinous visitors to annually sojourn at our health and pleasure resorts and thus leave us with that historic plethora of wealth which might act as a panacea for Ireland's ills" (cited in O'Connor, 1993 : 69). Over forty years ago, advertising efforts emphasised "Ireland's general holiday attractions (relaxed atmosphere, friendly people, scenery, sights, good roads, etc.) and special interest holiday themes (fishing, motoring, golf, etc.)" (Gorman, ${ }^{4} 1961$ : 233).

Bord Fáilte, ${ }^{5}$ the organisation responsible for the marketing of Ireland as an attractive tourism destination abroad, has led an active communication policy in France since the late 1960s. Given that such an agency has little or no control over organic images, destination managers must rely on induced images in order to create a positive image and/or rectify a negative one. According to Dumortier (1992), even if knowledge of Ireland on the part of the French public remains limited, Bord Fáilte's campaigns have succeeded in building a strong and positive image of the country. However, as by Dumortier, this has reinforced the French romantic view of Ireland (seen more as an island of the past than a modern changing State). Bord Fáilte has used variants of the same themes throughout their advertising campaign in France since 1968. The three main aspects of the country that have formed the basis of the promotional material are the magnificent scenery of the west of Ireland (stone walls, sheep, donkeys, thatched cottages, beautiful coastlines); the pace of life (unhurried lifestyles, quiet roads); and the people (warm, hospitable, with a good sense of humour) (Publicis, 1990, 1994). The publicity themes employed by Bord Fáilte have often been adopted by the national air and sea carriers, as well as by travel agencies and certain products, for example Guinness and Jameson (Dumortier, 1992 : 86), and this has served to reinforce the image of Ireland as portrayed in France by the state agency.

Anecdotal evidence highlighted in the media has recently focused attention on a number of threats to the Irish tourism product. The image of Ireland as a "Tiger" economy seems incongruous with the usual presentation of a rather backward green island (O'Sullivan, 1998; Dunne, 1999). Pressures on the environment exerted by the fast-paced economy, tourism development and the burgeoning litter problem are becoming increasingly obvious (McDonald, 1998; Hogan, 1999). Furthermore, the industry is challenged by labour shortages as well as the dilution of its famed fáilte or welcome. It is against this background that the French tourism market to Ireland is showing increasing signs of stagnation, highlighting the need to continuously assess and modify Ireland's destination image in France and elsewhere. The challenge, therefore, is to try and maintain the basis of appeal (scenery and people), to acknowledge Ireland's recent modernization and the threats posed by it, and to expand product awareness in an attempt to bridge the gap between the old and the new images.

For years, the image presented has focused on the beautiful scenery, welcoming people, and relaxed pace of life. Those factors have acted as appealing forces, a fact to which the increase in tourist arrivals since the 1980 s can attest. A destination would be ill-advised to radically alter its tourism image if it appeals to the target market. However, it must first be established that the destination is genuinely able to provide what the image suggests; in other words, that the image really corresponds to an experience realistically available to the visitor and does not only exist 
in brochures. Satisfied tourists are probably the best and most cost-effective marketing available for any destination in terms of both repeat visits and word-ofmouth promotion: without a high level of repeat visits, marketing can become very costly and maintaining the market shares increasingly difficult. But is the image of Ireland portrayed internationally consistent with what the destination now has to offer? Image change efforts are essentially wasted if baseline data establishing the present image position are not known (Gartner, 1993); however, few destination image studies to date have focused specifically on either Ireland or France, ${ }^{6}$ and none have analysed the image of Ireland as a tourism destination in France. Consequently, our study, carried out during the month of August 1998, addressed the dearth of knowledge relative to Ireland's destination image in France.

\section{Survey of French Tourists to Ireland}

We have previously highlighted the he need to ensure the compatibility of pre-visitation expectations with experience at the destination. A destination must, therefore, be able to assess the image held by visitors prior to visitation so that efforts can be made to match expectations with reality, and a pre-visitation questionnaire is an essential component of the image appraisal process. Consequently, it was decided to develop a two-part questionnaire to measure Ireland's destination image, both preand post-visitation. The three national airports (Cork, Dublin and Shannon) and the two ferryports with direct links to France (Ringaskiddy in Cork and Rosslare in Wexford) were chosen as the points of distribution, and a total of 1011 two-part questionnaires were distributed; 560 responses $(55 \%)$ were returned. That compares well with the number of French respondents to Bord Fáilte's 1999 VAS (552 distributed and 335 returned).

\section{Pre-Visitation Questionnaire}

Pre- and post-visitation questionnaires were employed in order to gauge the effect of visitation on the image held. In the pre- visitation (arrival) questionnaire, respondents were asked to rate each of 18 attributes on a scale of 1 to 5 according to how they thought Ireland would perform (where $1=$ "very poor performance" and $5=$ "very good performance"). The performance ratings of Ireland according to these attributes are outlined below in Table 1.

Table 1 above shows that respondents felt Ireland would perform best as regards beautiful scenery, calm/tranquillity, the welcome of the people, the potential for discovery, nightlife/entertainment, a relaxed pace of life, the environment, and culture/history; all these attributes obtaining expected mean ratings greater than four. Clearly, therefore, Ireland's expected or pre-visitation performance corresponds to the core elements of Ireland's appeal as a tourism destination that have formed the basis of Bord Fáilte's promotional approach for over forty years, summarised as "people, pace and place," which implies that the image of Ireland as a tourism destination receives widespread acceptance in the French market.

\section{Post-Visitation Questionnaire}

In the post-visitation (departure) questionnaire, respondents were asked to rate certain attributes on a scale of 1 to 5 according to how they thought Ireland was performing (where 1 = "very poor performance" and $5=$ "very good performance"). The ranking of Ireland's performance with respect to these attributes is presented in Table 2.

Respondents reported that Ireland was performing best as regards beautiful scenery, calm/tranquillity, nightlife/entertainment, the welcome of the people, a relaxed pace of life, and the potential afforded by the destination for discovery (i.e. each of these attributes received a performance mean rating greater than four). On the surface, this suggests that the experience of Ireland corresponds to the key elements of Ireland's projected tourism image, namely "people, pace and place." However, these results taken independently do not provide a complete description of Ireland's performance as a tourism destination. Tourism images are significant because of how they impact on the level of satisfaction with the tourist experience, which is critical as regards positive word-of-mouth recommendations and repeat visits to the destination. The larger the difference between image and reality, that is between expectations and experience, the more likely it is that a tourist will be dis-

\begin{tabular}{|l|c|c|}
\hline \multicolumn{2}{|c|}{ Trench fourists' pre-visitation performance rating of destination attributes in Ireland } \\
\hline Attribute & $\begin{array}{c}\text { Percentage rating Ireland's } \\
\text { expected performance as } \\
\text { 'good /very good' (n=281) }\end{array}$ & Mean rating \\
\hline Beautiful scenery & 95 & 4.70 \\
\hline Calm/tranquillity & 88 & 4.38 \\
\hline Welcome & 86 & 4.34 \\
\hline Discover something new & 84 & 4.34 \\
\hline Nightlife/entertainment & 82 & 4.25 \\
\hline Relaxed pace of life & 78 & 4.18 \\
\hline Environment & 76 & 4.09 \\
\hline Culture/history & 75 & 4.02 \\
\hline Litter free & 47 & 3.43 \\
\hline Services (restaurant/shop) & 47 & 3.49 \\
\hline Pretty towns & 46 & 3.48 \\
\hline Activities/sports & 39 & 3.11 \\
\hline Family/friends & 37 & 2.81 \\
\hline Price/quality ratio & 35 & 3.13 \\
\hline Climate & 31 & 2.98 \\
\hline Access (cost/means) & 28 & 2.99 \\
\hline Economic dev./urbanisation & 27 & 2.99 \\
\hline Source: Primary research (note: results are presented in rank order rather than the order in which & \\
\hline they appeared in the questionnaire). & & \\
\hline
\end{tabular}


TABLE 2

French tourists' post-visitation performance rating of destination attributes in Ireland

\begin{tabular}{|l|c|c|}
\hline Attribute & $\begin{array}{c}\text { Percentage rating Ireland's } \\
\text { expected performance as } \\
\text { 'good /very good' (n=281) }\end{array}$ & Mean rating \\
\hline Beautiful scenery & 95 & 4.71 \\
\hline Calm/tranquillity & 88 & 4.32 \\
\hline Nightlife/entertainment & 81 & 4.19 \\
\hline Welcome & 80 & 4.21 \\
\hline Relaxed pace of life & 79 & 4.16 \\
\hline Discover something new & 78 & 4.15 \\
\hline Environment & 76 & 3.98 \\
\hline Culture/history & 69 & 3.94 \\
\hline Services (restaurant/shop) & 63 & 3.69 \\
\hline Pretty towns & 54 & 3.52 \\
\hline Family/friends & 47 & 3.16 \\
\hline Litter free & 42 & 3.18 \\
\hline Climate & 38 & 3.18 \\
\hline Activities/sports & 37 & 3.17 \\
\hline Price/quality ratio & 34 & 3.08 \\
\hline Economic dev./urbanisation & 32 & 3.12 \\
\hline Access (cost/means) & 28 & 2.89 \\
\hline Source: Primary research (note: results are presented in rank order rather than the order in wh they oppecred in the questionnaire).
\end{tabular}

satisfied. A more meaningful analysis of performance thus requires the comparison of pre-visitation expectations with the post-visitation results or experience.

\section{Pre- and Post-Visitation Performance Ratings Compared}

The pre-visitation (expected) and post-visitation (actual) performance ratings for each of the seventeen attributes are listed in Table 3 as well as the difference between both means.

A comparison between the pre- and postvisitation means reveals that the travel experience modified the image of Ireland amongst French visitors in a positive direction for seven attributes and a negative direction for ten attributes. The results for each attribute are discussed in detail below, according to whether they received a positive or negative evaluation.

\section{Positive Evaluations}

Beautiful scenery received the highest preand post-visitation performance ratings of all attributes. There was a slight positive difference between the pre- and post-visitation mean scores $(+.01)$, implying that actual performance exceeded the already high level of anticipated performance. This suggests that one of the key facets of Ireland's appeal as a destination corresponds to expectations. Six other attributes surpassed the expected performance ratings; namely, services (in terms of restaurants/shops) $(+.20)$, pretty towns $(+.04)$, climate $(+.20)$, activities/sports $(+.06)$, family/friends $(+.35)$, and economic development/urbanisation (+.13). A number of reasons can be advanced to account for the positive evaluations received by these attributes: firstly, Ireland has generally received relatively poor evaluations in Bord Fáilte's Visitor Attitudes Surveys as regards food/restaurants and shopping, but increasing affluence in Ireland has undoubtedly stimulated improvements in that respect. Secondly, several tourist areas are involved in development initiatives such as the "Tidy Towns' Competition," designed to stimulate environmental consciousness in communities, and this may account for the positive rating of towns. Thirdly, many respondents enjoyed relatively good weather during their holiday in Ireland during August 1998. Fourthly, activity and sports tourism (for example, golf) has benefited greatly from increased investments in recent years. Fifthly, a number of respondents who had visited Ireland more than once indicated that they had reencountered friends, and a proportion had visited family members now residents in Ireland. Lastly, the positive rating of economic development/urbanisation is clearly linked with the Celtic Tiger phenomenon and resulting unprecedented growth in the Irish economy over the last five years: this finding is particularly interesting as it denotes a realistic acceptance amongst French visitors of modern urban Ireland, as it co-exists with the more traditional coastal and rural destinations.

\section{Negative Evaluations}

Regarding the welcome of the people, the post-visitation performance mean was lower than the pre-visitation mean (-.13). This indicates that one of the key elements of Ireland's appeal does not live up to expectations and corroborates anecdotal evidence as well as findings from the most recent Visitor Attitudes Survey (Bord Fáilte, 2000b) regarding threats to Ireland's tourism image. The tourism industry in Ireland is encountering difficulties with respect to the recruitment of staff and many employers now rely on workers from abroad. However, this may have serious implications in an Irish context where the allure of the native people is considered to be an integral component of the tourism product. Furthermore, a growing number of reports suggest that the warmth of an Irish welcome is no longer guaranteed, perhaps the inevitable outcome of the increase in the pace of life and economic development (Humphreys, 1999; Burke, 2000; Dunne, 2001).

The performance mean scores for a number of other attributes also decreased after visiting the country; namely, discover something new, the environment, litter, price/quality ratio, and access. The negative evaluation of the discovery attribute suggests that Ireland is not seen as particularly distinctive or unique. The negative reappraisal of the environment and litter also confirms the anecdotal evidence referred to earlier: this is a serious 


\begin{tabular}{|l|l|l|l|}
\hline \multicolumn{4}{l}{ TABLE 3 } \\
Pre- and post-visitation performance scores compared \\
\hline Aftribute & $\begin{array}{l}\text { Pre-visitation } \\
\text { performance } \\
\text { mean }\end{array}$ & $\begin{array}{l}\text { Post-visitation } \\
\text { performance } \\
\text { mean }\end{array}$ & $\begin{array}{l}\text { Difference } \\
\text { performance } \\
\text { means (+/-) }\end{array}$ \\
\hline Beautiful scenery & 4.70 & 4.71 & .01 \\
\hline Welcome & 4.34 & 4.21 &. .13 \\
\hline Discover something new & 4.34 & 4.15 &. .19 \\
\hline Environment & 4.09 & 3.98 &. .11 \\
\hline Calm/tranquillity & 4.38 & 4.32 & -.06 \\
\hline No litter & 3.43 & 3.18 & -.25 \\
\hline Culture/history & 4.02 & 3.94 & -.08 \\
\hline Price/quality ratio & 3.13 & 3.08 & -.05 \\
\hline Relaxed pace of life & 4.18 & 4.16 &. .02 \\
\hline Access (cost/means) & 2.99 & 2.89 &. .10 \\
\hline Nightlife/entertainment & 4.25 & 4.19 & -.06 \\
\hline Services (restaurant/shop) & 3.49 & 3.69 & .20 \\
\hline Pretty towns & 3.48 & 3.52 & .04 \\
\hline Climate & 2.98 & 3.18 & .20 \\
\hline Activities/sports & 3.11 & 3.17 & .06 \\
\hline Family/friends & 2.81 & 3.16 & .35 \\
\hline Economic dev./urbanisation & 2.99 & 3.12 & .13 \\
\hline
\end{tabular}

(such as activities/sports), which are common to most locations. Those attributes that received high pre-visitation performance scores may be presumed to compensate for those that received poor pre-visitation performance ratings, since visitors still choose to come to Ireland. In the case of Ireland and France, attributes such as beautiful scenery, calm/tranquillity, welcoming people, potential for discovery, nightlife/entertainment, pace of life, culture/history, and environmental factors (all of which had expected mean scores greater than four) "compensate" for price/quality, litter, and access. However, if the compensating factors do not perform well in reality, there will be serious consequences in terms of repeat visits and word-of-mouth recommendations. French visitors to Ireland reported that scenery lived up to and exceeded expectations, but all other compensating factors received negative post-visitation evaluations. It is important to note also that because the pace of change has greatly accelerated since the primary research for this study was

issue, not least because of how it may affect one of Ireland's greatest tourism assets-the scenery. As an island destination, Ireland is not generally regarded as a low cost/easy access holiday option; nonetheless, it is worrying that these attributes scored lower on the post-visitation survey.

Calm/tranquillity received a higher pre-visitation than post-visitation score (-.06). Similar scenarios are evident with respect to relaxed pace of life (-.02) and nightlife/ entertainment (-.06). The calm/tranquillity and pace of life scores can obviously be correlated with the effects of Ireland's recent economic development, such as the well-documented traffic problems resulting from the huge increase in car ownership, and which have led to virtual gridlock in many Irish cities and medium-sized towns. The nightlife/entertainment score may be accounted for by the fact that visitors are sometimes disappointed by the lack of music in pubs, which they have been led to expect as an everyday phenomenon by the pervasive images of Bord Fáilte brochures. Linked with the nightlife/entertainment attribute is culture/history, which also declined after visitation. The lack of internationally renowned cultural sites in Ireland has resulted in a greater emphasis being placed on the promotion of "living culture" or culture as a way of life (Richards, 1996). The negative evaluation of culture is, therefore, understandable given that the living culture is affected by the welcome and the pace of life, both of which received negative post-visitation evaluations. The negative reappraisal of the culture attribute is of particular concern given that cultural tourism represents a potential growth sector in the increasingly competitive tourism industry (Bywater, 1993; Richards, 1996) and may be seen as an important factor of differentiation between Ireland and competing destinations.

A destination is comprised of a mixture of different attributes. The comparison of preand post-visitation performance scores shows that experience of Ireland modified the images held by French visitors in both a positive and negative direction. However, the negative re-evaluations include those attributes that could be thought to differentiate Ireland from its competitors, for example, the welcome and relaxed pace of life, whilst the positive re-evaluations are mainly in terms of generic destination attributes carried out, it is reasonable to assume that many of the problems and issues identified in this survey (for example, traffic congestion) have disimproved further during the intervening period.

\section{Conclusion}

In the past, Ireland differed from many other tourism destinations in Europe due to its relative lack of economic development, and that was reflected in the projected images. Since the 1960s, Bord Fáilte has promoted Ireland as a friendly, pre-modern and scenic destination in the international marketplace. The general media, as well as non-tourism products such as Guinness, have often reinforced that image. In the French market, in particular, the combined images promoted have centred on the beautiful scenery, welcoming people, and relaxed pace of life. Today, "people, pace and place" remain the core attractions of an Irish holiday experience, but in the last ten years Ireland has undergone considerable economic growth and modernization, with consequent dramatic changes in the Irish way of life, which has compromised the continuing promotion of Ireland on that basis. The image of Ireland consistently 
portrayed in the past is no longer completely accurate. We have outlined a number of specific threats, for example pressures on the environment and the failing fáilte (Gaelic for "welcome"); the baseline data provided by our pre-visitation questionnaire, set against our post-visitation questionnaire, made it possible to evaluate how the destination is actually performing, and to indicate how overall high satisfaction levels can mask individual areas where the experience does not correspond to the expected performance. It must be acknowledged that the images that were undoubtedly representative of Ireland until quite recently are no longer a completely accurate portrayal of Ireland as a tourism destination in the 21 st century. In the past, those images have acted as an appealing force, a fact to which the increase in tourist arrivals can attest. However, the current stagnation of the French market to Ireland and the concerns evident in the responses of the visitors surveyed in our sample clearly pose challenges for the Irish tourism authorities. The role of visitor satisfaction with respect to repeat visits and word-ofmouth recommendations is widely acknowledged as being significant, and underscores the need for the tourism industry to ensure consistency between the image promoted and the reality of the destination.

There appears to be a tacit reluctance amongst those involved in destination image management to address the reality of Ireland's changing socio-economic circumstances in promotional material. Perhaps there is a fear that if Ireland is no longer portrayed as a pre-modern, friendly, green destination, tourists will not come. That is undoubtedly a legitimate concern, however, the consequences of false or inaccurate advertising may be even more serious in terms of repeat visits and vital word-of-mouth recommendations. The fact that the economic development/urbanisation attribute received a higher post- than pre-visitation rating suggests that even though many of the problems identified in this survey as well as others have been adversely affected by modernization (such as changes in the Irish way of life, and increased traffic and pollution), visitors are not necessarily re- pulsed by the fact that Ireland has evolved. Moreover, it should be possible to capitalise on certain aspects of the recent modernization-such as improvements to the national road network and the availability of funding for cultural development as noted in a recent edition of Newsweek (Power, 2001)-to the benefit of the tourism industry, and to highlight these within marketing campaigns.

Ironically, in many cases, it is those attributes which policy-makers can influence that disimproved (for example, litter and price/quality), whilst those outside of government or industry control met or exceeded pre-visitation expectations (for example, scenery, climate and family/friends). Although that raises serious questions as to whether Irish people feel those aspects of society are worth preserving for themselves or tourists, it is nonetheless encouraging in that it implies that the situation is not beyond redress and measures can be taken to ensure the continued success of the tourism industry in Ireland. While a complete reversal of Ireland's current destination positioning would undoubtedly have a detrimental effect on the number of visitors, a careful appraisal of what Ireland as a destination has to offer potential tourists could facilitate a gradual reorientation of the marketing focus to reflect the changing realities of the Irish life.

\section{Sinead O'leary is a Research Fellow at} the National Centre for Tourism Policy Studies, University of Limerick (Ireland). A Public Affairs graduate from the University of Limerick, she completed her PhD Degree within the Tourism Centre in 2001. Her thesis was entitled Ireland's image as a Tourism Destination in France.

\section{Geraldine Sheridan is Associate} Professor of French at the University of Limerick. She has published widely on aspects of eighteenth-century and the histo$r y$ of ideas, including a monograph on Nicolas Lenglet Dufresnoy and the Literary Underworld of the Ancien Regime.
Notes

1 Nevertheless, it is important to remember that destination image is not the only factor influencing the choice of a particular destination, and that many other factors are involved in the destination selection process, including price, income, age, education, and annual leave entitlements.

2 In Bord Fáilte's 1999 Visitor Attitudes Survey, $49 \%$ of visitors mentioned advice from a friend, relative, or business associate as an important influence factor in choosing Ireland (Bord Fáilte, 2000b). The importance of word-of-mouth recommendations for Ireland is also highlighted in past surveys (1983, 1988, 1995, 1997).

3 Burke was the first to explain beauty and the sublime purely in terms of the process of perception and its effect upon the perceiver.

4 Then Publicity Manager for Bord Fáilte.

5 Tourism Ireland Limited, a new North/South tourism company was established in 2000 by Bord Fáilte and the Northern Ireland Tourist Board: responsibility for overseas strategic destination marketing was transferred to that new company in 2001.

6 Exceptions include Ehemann (1977); Quinn (1989); O’Regan (1997); Gleeson (1999); Prentice and Andersen (2000)-who examined various aspects of Ireland's tourism destination image; Mohamed (1988)-who studied the tourism image of Morocco in France; Dybka (1988)-who investigated French visitors' images of Canada; and Bignon et al (1998)-who evaluated French perceptions and images of the US as a destination.

7 Bord Fáilte's Visitor Attitudes Survey (VAS), which aims to assess visitors' reactions regarding a range of different aspects of their visit to Ireland, is carried out solely on a post-visitation basis.

\section{Bibliography}

Baloglu, S., and K.W. McCleary (1999), « A Model of Destination Image Formation ", Annals of Tourism Research, 26 (1), p. 868-897.

Bignon, V.N., W.E. Hammitt, and W.C. Norman (1998), « French Perceptions and Images of the United States as a Destination Country », Tourism Analysis, 3, p. 159-171.

Bord Fáilte (2000a), Tourism Facts, Dublin, Bord Fáilte.

Bord Fáilte (2000b), Visitor Attitudes Survey, Dublin, Bord Fáilte.

Bord Fáilte (2000c), Marketing Ireland to the World: Annual Review 2000 and Outlook 2001, Dublin, Bord Fáilte. 
Burke, S. (2000), «Welcome Mat Begins to Display Signs of Wear », Irish Times, 17 April.

Bywater, M. (1993), « The Market for Cultural Tourism in Europe ", EIU Travel and Tourism Analyst, 6, p. 30-46.

Chon, K.S. (1990), « The Role of Destination Image in Tourism: A Review and Discussion », The Tourist Review, 45 (2), p. 2-9.

Dann, Graham (1996), « The People of Tourist Brochures ", in The Tourist Image: Myths and Myth Making in Tourism, T. Selwyn. (ed.), Chichester, John Wiley \& Sons, p. 61-81.

Department of Tourism, Sport and Recreation (2000), Expenditure Review of the Overseas Tourism Marketing Initiative, Dublin, DTSR.

Dumortier, Denis (1992), «L'image de l'Irlande en France à travers la publicité de Bord Fáilte », Hommes et Terres du Nord, 2, p. 86-88.

Dunne, J. (1999), « Bord Fáilte Prepares New Corporate Plan », Irish Times, 4 June.

Dunne, J. (2001), « British Holidaymakers Think Irish Less Friendly », Irish Times, 20 February.

Dybka, J. (1988), « Overseas Travel to Canada: New Research on the Perceptions and Preferences of the Pleasure Travel Market ", Journal of Travel Research, 26 (4), p. 12-15.

Ehemann, J. (1977), « What Kind of Place Is Ireland: An Image Perceived through the American Media ", Journal of Travel Research, 16, fall, p. 28-30.

Fayeke, P.C., and J.L. Crompton (1991), «Image Difference between Prospective, First-Time, and Repeat Visitors to the Lower Rio Grande Valley », Journal of Travel Research, 30 (2), p. $10-16$.

Fayos-Sola, Eduardo (1996), « Tourism Policy: A Midsummer Night's Dream? 》, Tourism Management, 17 (6), p. 405-412.

Gartner, W.C. (1993), «Image Formation Process ", Journal of Travel and Tourism Marketing, 2 (2/3), p. 191-215.

Gleeson, Maureen (1999), « Tourism City Image: The Case of Limerick », unpublished M.B.S. thesis, College of Business, University of Limerick.

Goodall, Brian (1992), « How Tourists Choose Their Holidays: An Analytical Framework », in Marketing in the Tourism Industry: The Promotion of Destination Regions, B. Goodall and G. Ashworth (eds.), London: Routledge, p. 1-17.

Gunn, Clare (1972), Vacationscape: Designing Tourist Regions, Austin, University of Texas.

Hogan, T. (1999), « Environment in Growing Peril as Economy Booms », Irish Independent, 15 July.
Holmquist, K. (1999), « Visitors to Get Fáilte with a Foreign Blas », Irish Times, 3 May.

Humphreys, J. (1999), « Tourism Executive Fears a Bored Fáilte », Irish Times, 1 April.

Hunt, J.D. (1975), « Image as a Factor in Tourism Development », Journal of Travel Research, 13, p. 1-7.

Jackson, M.S., C.L. Schmierer, and M. Nicol (1997), « Influences on Tourist Decision Making ", in Tourism Research: Building a Better Industry, Proceedings of the Australian Tourism and Hospitality Research Conference, R. Bushell (ed.), Sydney 6-9 July, Canberra, Bureau of Tourism Research, p. 288-300.

Jenkins, O. (1997), « Understanding and Measuring Tourists Destination Images ", in Tourism Research: Building a Better Industry, Proceedings of the Australian Tourism and Hospitality Research Conference, R. Bushell (ed.), Sydney 6-9 July, Canberra, Bureau of Tourism Research, p. 1-18.

Kent, P. (1991), «Understanding Holiday Choices ", in The Tourism Industry: An International Analysis, M.T. Sinclair and M.J. Stabler (eds.), Wallingford, CAB International, p. 165-183.

Khan, F. (2000), « The Myth of Céad Milé Fáilte and all that Blarney ", Irish Independent, 17 April.

Kneafsey, M. (1994), « The Cultural Tourist: Patron Saint of Ireland? », in Culture, Tourism and Development: The Case of Ireland, $\mathrm{U}$. Kockel (ed.), Liverpool, Liverpool University Press, p. 103-116.

McClellan, R.C., and K.D. Foushcee (1983), « Negative Images of the United States as Expressed by Tour Operators from Other Countries », Journal of Travel Research, 22 (1), p. $2-5$.

McDonald, F. (1998), « Tourism May Be a Problem in Itself », Irish Times, 19 August.

McInnis, D.J., and L.L. Price (1987), « The Role of Imagery in Information Processing: Review and Extensions ", Journal of Consumer Research, 13 March, p. 473-491.

Mill, R.C., and A.M. Morrison (1992), The Tourism System: An Introductory Text, $2^{\text {nd }}$ ed., Englewood Cliffs (NJ), Prentice Hall.

Mohamed, M. (1988), « Moroccan Tourism Image in France », Annals of Tourism Research, 15 (4), p. 558-561.

Morgan, N., and A. Pritchard (1998), Tourism Promotion and Power: Creating Images, Creating Identities, Chichester, John Wiley \& Sons.

O'Connor, Barbara (1993), « Myths and Mirrors: Tourist Images and National Identity », in Tourism in Ireland: A Critical Analysis, Barbara
O'Connor and Michael Cronin (eds.), Cork, Cork University Press, p. 68-85.

O'Loughlin, A. (2000), « Tourism and Hotels Hiring Foreign Staff to Ease Jobs Crisis », Irish Independent, 27 January.

O'Regan, Michael (1997), « Ireland's Changing Image and its Convention Visitors », unpublished M.B.S. thesis, College of Business, University of Limerick.

O'Sullivan, K. (1998), « $£ 100 \mathrm{~m}$ Deal for Tourism Fund May Involve Levy », Irish Times, 16 December.

Pizam, A., and A. Milman (1993), «Predicting Satisfaction Among First-Time Visitors to a Destination by Using the Expectancy Disconfirmation Theory », International Journal of Hospitality Management, 12 (2), p. 197-209.

Power, C. (2001), « What Happened to Irish Art? », Newsweek, 20 August, p. 42-45.

Prentice, R., and V. Andersen (2000), « Evoking Ireland: Modelling Tourist Propensity », Annals of Tourism Research, 27 (2), p. 490-516.

Publicis Étoile (1990), La construction de l'image touristique de l'Irlande, Paris, Agence Publicis Étoile.

Publicis Étoile (1994), L'Irlande: ou comment garder un client pendant 25 ans sans changer de campagne, Paris, Agence Publicis Étoile.

Quinn, B. (1989), « Imagery in Tourism Promotion: A Case Study of Ireland as a Tourist Destination in Continental Europe ", unpublished M.A. thesis, Maynooth, St. Patrick's College.

Quinn, B. (1994), «Images of Ireland in Europe: A Tourism Perspective ", in Culture, Tourism and Development: The Case of Ireland, U. Kockel, (ed.), Liverpool, Liverpool University Press, p. 61-73.

Richards, Greg (Ed.) (1996), Cultural Tourism in Europe, Wallingford (UK), CAB International.

Siggins, L. (2000), « Newfoundlanders Answer West's Call », Irish Times, 17 March.

Stocks, J. (1996), « Heritage and Tourism in the Irish Republic - Towards a Giant Theme Park? », in Tourism and Culture: Image, Identity and Marketing, M. Robinson et al. (eds.), Sunderland, Centre for Travel and Tourism in association with Business Education Publishers Ltd., p. 251-260.

Van Raaij, W.F. and D.A. Francken (1984), «Vacation Decisions, Activities and Satisfaction », Annals of Tourism Research, 11, p. 101-112.

Vogt, C.A., S.I. Stewart, and D.R. Fesenmaier (1998), « Communication Strategies to Reach First-Time Visitors », Journal of Travel and Tourism Marketing, 7 (2), p. 69-89. 